\title{
FIELD EVALUATION OF SWEETPOTATO CULTIVARS FOR RESISTANCE TO SCLEROTINIA ROT
}

\author{
P.G. BROADHURST ${ }^{1}$, S.L. LEWTHWAITE ${ }^{2}$ and C.M. TRIGGS ${ }^{3}$ \\ ${ }^{I}$ New Zealand Institute for Crop \& Food Research Ltd, \\ Mt Albert Research Centre, Private Bag 92169, Auckland, \\ ${ }^{2}$ Pukekohe Research Centre, Cronin Rd, R D 1, Pukekohe \\ ${ }^{3}$ Department of Statistics, University of Auckland, Private Bag 92019, Auckland
}

\begin{abstract}
Sclerotinia rot is considered one of the most significant diseases of "kumara" or sweetpotato (Ipomoea batatas) in New Zealand. Many internationally sourced clones of sweetpotato brought into the country during recent years have appeared resistant to Sclerotinia rot in the field. In order to confirm these observations, two local and two internationally sourced sweetpotato cultivars were screened for resistance toSclerotinia rot in a field trial established at Pukekohe. Plants were artificially inoculated with an isolate of S. sclerotiorum from sweetpotato in February 1996. Disease assessments based on the proportion of diseased to healthy vine tissue about the plant crown were conducted in April 1996. Significant differences in the levels of diseased vine tissue were found between all of the cultivars evaluated. 'Toka Toka Gold' (NZ) had a high level of diseased tissue (33\%), '93N9/2' (Taiwan) and 'Owairaka Red' (NZ) both had moderate levels (11\% and $8 \%$, respectively), and 'Beauregard' (USA) had a low level of diseased vine tissue (1\%). The commercial sweetpotato cultivars predominantly grown in New Zealand were found susceptible toSclerotinia rot. The use of new sweetpotato selections that show resistance to Sclerotinia rot, should significantly reduce losses caused by the disease.
\end{abstract}

Keywords: sweetpotato, kumara, cultivars, Sclerotinia sclerotiorum, disease resistance

\section{INTRODUCTION}

Sweetpotato (Ipomoea batatas (L.) Lam.), known locally as "kumara", was the major vegetable cultivated by pre-European Maori in New Zealand and was of great traditional importance (Coleman 1978). The crop still remains an important fresh vegetable food item with over \$15 million in annual household expenditure spent on sweetpotato in 1996 (Anon 1996). The latest complete set of regional figures on sweetpotato production shows that 1048 ha of sweetpotato were grown in the 1993/94 season, with the majority of the crop (903 ha) being produced in Northland (Anon. 1997).

In surveys completed by growers in the Northland region both in 1993 and 1994, Sclerotinia rot (commonly referred to as "pink rot") was considered one of the most significant disease problems of sweetpotato (Lewthwaite unpubl.; Broadhurst unpubl.). The disease is usually attributed to S. sclerotiorum (Lib.) de Bary (Dingley 1969; Coleman 1978) but may also be caused by S. minor Jagger (Boesewinkel 1977). S. sclerotiorum has been recorded on 101 host plants in New Zealand (Pennycook 1989) and is of considerable economic importance (Dingley 1969). It occurs on sweetpotato in the propagation beds and in the field. In the beds, infected plants collapse. Portions of vines may also collapse in the field, but if the crown is infected, the whole plant may be killed (Coleman 1978). Sclerotia (fungal resting bodies) can form on infected plant tissue and become a source of infection if they remain in the soil.

Two local sweetpotato cultivars account for about $95 \%$ of the total crop volume in

Proc. 50th N.Z. Plant Protection Conf. 1997: 89-92 
New Zealand; 'Owairaka Red' has been estimated to account for about 80 to $90 \%$ of the crop and 'Toka Toka Gold' most of the remainder (Lewthwaite 1991). In order to broaden the genetic base of the crop, internationally sourced clones are being trialed in New Zealand. While undergoing field trials it appeared that many of these clones were resistant to Sclerotinia rot. To confirm these observations and to develop an effective disease assessment procedure that could be used in future field evaluations of sweetpotato germplasm, two local and two internationally sourced sweetpotato cultivars were evaluated for resistance to Sclerotinia rot in a field trial established at Pukekohe in the $1995 / 96$ season.

\section{Field trial site and experimental design}

\section{MATERIALS AND METHODS}

The site chosen for the trial was an area of land at the Pukekohe Research Centre that had no previous history of Sclerotinia disease. Fertiliser (30\% potassic superphosphate) was broadcast over the area at $1 \mathrm{t} / \mathrm{h}$ a and incorporated into the Patumahoe clay loam soil.

Four sweetpotato cultivars; 'Owairaka Red' and 'Toka Toka Gold' from New Zealand (Lewthwaite 1991), '93N9/2' (a breeding line supplied by the Asian Vegetable Research and Development Centre, Taiwan) and 'Beauregard' from the USA (Rolston et al. 1987), were planted in the trial in November 1995. The trial was set out in a row and column design incorporating nine replicate plots of each cultivar, arranged in a $6 \mathrm{x}$ 6 array of plots. Ten rooted apical stem cuttings were planted in each plot, which consisted of two mounded rows with five plants in each. Plant density was similar to that used in commercial practice, with a row width of $75 \mathrm{~cm}$ and an inter plant spacing of 30 $\mathrm{cm}$. The trial area was surrounded on all sides by a guard row of plants ('Toka Toka Gold') to minimise any edge effects.

\section{Inoculum preparation and plant inoculation}

Inoculum consisted of oat grains colonised by S. sclerotiorum. Oat grains were soaked in water overnight, drained thoroughly, transferred into glass preserving jars, and autoclaved twice for $20 \mathrm{~min}$ at $121^{\circ} \mathrm{C}$ (on consecutive days). The jars of autoclaved grains were inoculated with an isolate of S. sclerotiorum (ICMP 13158, originated from sweetpotato at Pukekohe) held in the International Collection of Micro-organisms from Plants, Landcare Research, Auckland. Cultures of ICMP 13158 were grown on potato dextrose agar (PDA) plates and pieces of agar colonised by the fungus used to inoculate the jars of sterile oat grains. Inoculated material was incubated on a laboratory bench (20$25^{\circ} \mathrm{C}$, receiving diffuse daylight) until the grains were completely colonised by mycelium of the fungus. The infested grains were then removed from the jars and thoroughly mixed together in a large plastic bin.

Plots of sweetpotato plants in the trial were inoculated in February 1996. A level volume of the $S$. sclerotiorum infested grains $(170 \mathrm{ml}$, about $90 \mathrm{~g})$ was evenly distributing on the soil surface along the centre of each row. Inoculum was not applied to the guard rows surrounding the inoculated plots. To help provide a humid environment conducive to Sclerotinia disease establishment and development, overhead irrigation was applied to the trial site during periods of hot, dry weather.

\section{Disease assessments and data analysis}

Disease assessments were conducted in April 1996. A circular plastic template (31 $\mathrm{cm}$ in diameter) was centred over the crown of each sweetpotato plant in the plots and a knife used to cut the vines protruding from the outer edge of the template. Parts of vines that did not originate from the crown of the plant being assessed were removed and the remaining aboveground portions of vine within the circle (both healthy and diseased) placed in a labelled bag.

Two disease assessment procedures were conducted on each of the samples. In the first procedure, diseased and healthy portions of vine tissue were separated and the percentage of diseased vine tissue visually estimated and assigned a "disease score" on a scale of $0-4$, where: $0=0 \%, 1=1-25 \%, 2=26-50 \%, 3=51-75 \%$, and $4=76-100 \%$ diseased tissue. In the other disease assessment (a more laborious procedure), healthy and diseased portions of the vines were dried in an oven $\left(80^{\circ} \mathrm{C}\right.$ for $\left.72 \mathrm{hr}\right)$ and the percentage of diseased tissue calculated from the total weight of dry tissue. Plants in the uninoculated 
guard rows were also examined for the presence of disease to establish if Sclerotinia infection had occurred naturally at the trial site. Representative samples of diseased vine tissue were plated onto PDA to confirm that Sclerotinia was the cause of disease.

Data was analysed using analysis of variance. Percentage disease incidences were transformed to the logit scale to ensure approximate equality of variance.

\section{RESULTS AND DISCUSSION}

Disease levels in this trial were considerably less than that observed with natural infection in a previous field trial, where in some cultivars, entire crowns and exposed portions of storage roots had rotted. However, significant differences in the levels of diseased vine tissue $(\mathrm{P}<0.001)$ were found between all of the cultivars evaluated (Table $1)$.

\section{TABLE 1: Total dry weights of vine tissue sampled and levels of diseased tissue for four sweetpotato cultivars inoculated withSclerotinia sclerotiorum.}

\begin{tabular}{lcccc}
\hline Cultivar(origin) & $\begin{array}{c}\text { Mean total } \\
\text { dryweight } \\
\text { of tissue }(\mathrm{g})\end{array}$ & $\begin{array}{c}\text { Mean logit } \\
\text { (\% disease) }\end{array}$ & $\begin{array}{c}\text { Percentage } \\
\text { disease }^{1}\end{array}$ & $\begin{array}{c}\text { Mean disease } \\
\text { score }^{2}\end{array}$ \\
\hline
\end{tabular}

\begin{tabular}{lcccc}
\hline Beauregard(USA) & 7.7 & -4.1 & 1 & 0.4 \\
Owairaka Red (NZ) & 7.0 & -2.9 & 8 & 1.1 \\
93N9/2 (Taiwan) & 10.9 & -2.4 & 11 & 1.4 \\
Toka Toka Gold (NZ) & 9.8 & -1.0 & 33 & 2.5 \\
& & & & 0.12 \\
SED & 0.52 & 0.21 & & $<0.001$ \\
P-value & $<0.001$ & $<0.001$ & & \\
\hline
\end{tabular}

${ }^{1}$ Back-transformed from the mean logit percentage disease incidence.

${ }^{2}$ Based on visual estimates on a scale of $0-4$; where, $0=0 \%, 1=1-25 \%, 2=26-50 \%, 3=$ $51-75 \%$, and $4=76-100 \%$ diseased tissue.

'Toka Toka Gold' (NZ) had a high level of diseased tissue (33\%), '93N9/2' (Taiwan) and 'Owairaka Red' (NZ) both had moderate levels (11\% and 8\%, respectively), and 'Beauregard' (USA) had a low level of diseased vine tissue (1\%). The mean disease score given for each cultivar (based on visual estimates of the amount of diseased tissue) was found to be comparable with the percentage disease value (calculated from weights of dry tissue). Diseased vines were not observed on uninoculated 'Toka Toka Gold' plants in the guard rows surrounding the trial. S. sclerotiorum was re-isolated from diseased vine tissue on plants in the inoculated plots.

The distribution of disease scores (based on visual estimates of disease levels) for the four cultivars are shown in Fig. 1. Every 'Toka Toka Gold' plant had some diseased tissue and the distribution of disease scores was well spread (1-5), showing a wide range of disease development amongst individual plants. All 'Beauregard' plants had low disease scores (either 0 or 1), indicating resistance to Sclerotinia rot.

The commercial sweetpotato cultivars predominantly grown in New Zealand were found to be susceptible to Sclerotinia rot. It has been reported in the USA that the Sclerotinia fungi commonly destructive on lettuce, bean, celery, carrot, cabbage and many other vegetables, are of no importance and rarely occur on sweetpotato (Walker 1952). The use of new sweetpotato selections that show resistance toSclerotinia rot (e.g. 'Beauregard' from the USA), should significantly reduce losses caused by the disease. Our results confirm previous field observations of differences in susceptibility to Sclerotinia rot within internationally sourced sweetpotato germplasm. A disease assessment procedure based on visual estimates of diseased tissue could be used to evaluate sweetpotato clones for resistance to Sclerotinia rot directly in the field. 
Anonymous, 1996. What they like. N.Z. Commercial Grower 51(9): 24.

Anonymous, 1997. Agricultural Statistics 1994-1995. Statistics New Zealand, Wellington. $160 \mathrm{pp}$.

Boesewinkel, H.J., 1977. New plant disease records in New Zealand: records in the period 1969-76. N.Z. J. Agri. Res. 20: 583-589.

Beauregard

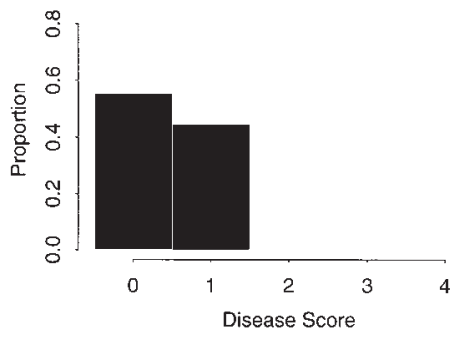

$93 \mathrm{~N} 9 / 2$

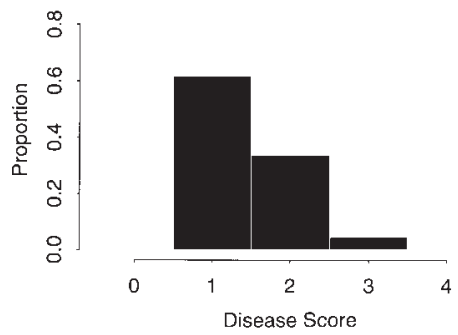

Owairaka Red

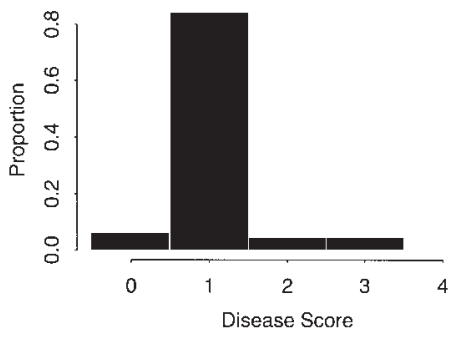

TokaToka Gold

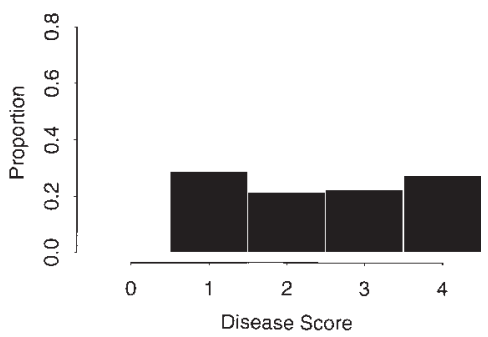

FIGURE 1: Distribution of Sclerotinia disease scores (based on visual estimates on a scale of $0-4$; where, $0=0 \%, 1=1-25 \%, 2=26-50 \%, 3=51-75 \%$, and $\mathbf{4}=\mathbf{7 6 - 1 0 0 \%}$ diseased tissue) for four sweetpotato cultivars.

Coleman, B.P., 1978. Kumara Growing. New Zealand Department of Agriculture Bulletin No.294. Government Printer, Wellington. 44 pp.

Dingley, J.M., 1969. Records of Plant Diseases in New Zealand. N.Z. Department of Scientific and Industrial Research, Bulletin 192. 298 pp.

Lewthwaite, S.L., 1991. Potential for introduced sweetpotato cultivars in New Zealand. Proc. Agronomy Soc. N.Z. 21:1-5.

Pennycook, S.R., 1986. Plant Diseases in New Zealand. Volume 2. Plant Diseases Division, DSIR, Auckland. 502 pp.

Rolston, L.H., Clark, C.A., Cannon, J.M., Randle, W.M., Riley, E.G., Wilson, P.W. and Robbins, M.L., 1987. 'Beauregard' sweet potato. HortSci. 22: 1338-1339.

Walker, J.C., 1952. Diseases of Vegetable Crops. McGraw-Hill Book Company, Inc., New York. 529 pp. 